\title{
CONFLICTS OF JURISDICTION IN ANTITRUST LAW: A COMMENT ON ORDOVER AND ATWOOD
}

\author{
Diane P. WoOd*
}

\section{INTRODUCTION}

Conflicts of jurisdiction among nations over the application of economic policy regulations like antitrust laws inevitably arise when international trade links the world so closely. Dr. Ordover and Mr. Atwood have looked at this problem through the large and the small end of the binoculars, respectively. Ordover has sketched broad categories of industrial policy where nations should and should not defer to one another's jurisdictional primacy; Atwood takes the rather rare case of a "pure export cartel" and concludes that national antitrust enforcers should go out of business when such cartels meet his specified criteria. Each author has made a number of interesting suggestions, but each has failed to recognize adequately the nature of a jurisdictional conflict, and to note the difference between resolution of such conflicts by means of jurisdictional rules and resolution of such conflicts in other ways. This article will sketch out the critical preliminary analysis and indicate the way in which it affects each author's conclusions.

\section{II}

\section{The Nature of Jurisdictional Conflicts}

A great deal of ink has been spilled in recent years explicating this subject, much of it by the American Law Institute in its recently completed project to revise the Restatement of Foreign Relations Law of the United States.' In brief, there can be at least two kinds of "jurisdictional" conflicts. The first and most fundamental conflict relates to the prescriptive jurisdiction of a nation, its competence under international law to create or to prescribe rules of conduct or status. The recognized bases of prescriptive jurisdiction include

\footnotetext{
Copyright $(9) 1988$ by Law and Contemporary Problems Assistant Professor of Law, The University of Chicago Law School.

During part of the time during which these comments were being prepared, the author was serving as a Special Assistant in the Foreign Commerce Section, United States Department of Justice Antitrust Division. The views expressed herein are solely those of the author and do not represent the positions of the Department of Justice.

1. Restatement (Revised) of the Foreign Relations Law of the United States, §§ 401-04, 421, 431, 1987 (unpublished) [hereinafter REVISEd RESTATEMENT ].
} 
territoriality and nationality. ${ }^{2}$ In other words, nations are entitled to prescribe rules that will control conduct or status for anyone located within the state's territorial area, and nations are entitled to prescribe rules that their citizens or subjects must obey. (The son of territorial jurisdiction, whose legitimacy has been debated sporadically at least since the case of the S.S. Lotus before the Permanent Court of International Justice in $1927,{ }^{3}$ is referred to as "effects jurisdiction" or "objective territoriality.") Two nations often have concurrent prescriptive jurisdiction, since a national of one may easily find himself or herself within the territory of another. No real "conflict of jurisdiction" arises in most of these cases, even if the two countries in question have prescribed different rules of conduct, since each country usually recognizes the legitimacy of the other's prescriptive jurisdiction. The only conflict is a substantive conflict of laws, which can be resolved through the usual mechanisms.

A conflict over prescriptive jurisdiction arises when one country disputes the fundamental right of another country to prescribe the rule of conduct at all. Taking an antitrust example referred to in Atwood's paper, such a conflict arose in the Watchmakers case, when Switzerland claimed that the United States had no business regulating the activities of the Swiss watch industry, either through U.S. antitrust law or otherwise. ${ }^{4}$ The United States had prosecuted the watchmakers' cartel on the theory that it was adversely affecting competition within the United States, relying on the theory of prescriptive jurisdiction that permits a nation to create rules for conduct occurring outside its territory that have effects within the territory. To some degree, international law recognizes this "objective territoriality" theory. Switzerland, however, disputed both the appropriateness of any use of the effects doctrine for economic activity and the particular application of the doctrine on the facts of the case.

Conflicts arise with even greater frequency in another area of international jurisdiction, usually termed enforcement jurisdiction. ${ }^{5}$ This concept refers to the efforts of a country, through whatever agencies it chooses, to implement its validly prescribed rules of law. Specific problems might arise in connection with a request for the production of documents located abroad, an effort to serve process on a defendant, or an effort to collect a fine imposed as a result of litigation. Countries are, if anything, even more sensitive to infringements

2. Id. § 402. See also FTC v. Compagnie de Saint-Gobain-Pont-a-Mousson, 636 F.2d 1300, 1315-17 (D.C. Cir. 1980).

3. France v. Turkey, 1927 P.C.I.J. (Ser. A) No. 10 (the S.S. Lotus case).

4. United States v. Watchmakers of Switzerland Info. Center, Inc., 1963 Trade Cas. (CCH) ๆ 70,600 (S.D.N.Y. 1962), judgment modified, 1965 Trade Cas. (CCH) \ 71,352 (S.D.N.Y. 1965). For a detailed account of the frictions between Switzerland and the United States occasioned by this lawsuit, see J. Rahl, Common Market and American Antitrust 311.63 (1970).

5. See Restatement (Second) of Foreign Relations Law of the United States $\S \S 20,40$ (1965). The Revised Restatement, supra note 1, distinguishes between enforcement jurisdiction $(\S 431)$ and adjudicatory jurisdiction $(\$ 421)$, while its 1965 predecessor did not. Because the discussion in the text does not depend upon the distinction drawn in the 1987 version, it follows the usage of the 1965 version. 
on their exclusive ability to enforce laws within their own territories than to overreaching exercises of prescriptive jurisdiction. One notorious example of an international conflict of enforcement jurisdiction arose between the U.S. courts and the Canadian courts over U.S. discovery requests for Canadian documents related to the alleged uranium cartel. ${ }^{6}$ The question was simple: Could a U.S. court with proper personal jurisdiction over an individual order that person to leave the United States, go to Canada, collect papers over the objection of the Canadian authorities, and return with the papers to the U.S. court? Many conflicts of jurisdiction between nations are fought at the enforcement level, although policy disputes on the underlying substantive law usually lurk in the background.

Sometimes conflicts arise over both prescriptive and enforcement jurisdiction, even when substantive disagreements are minimal. The United Kingdom, for example, has a set of competition laws prohibiting cartels and restrictive practices, ${ }^{7}$ and as a Member State of the European Economic Community, it also subscribes to the competition rules of articles 85 and 86 of the Treaty of Rome. ${ }^{8}$ Taken together, these rules are quite similar to the U.S. antitrust laws. The substantive similarity, however, has not prevented the most vociferous of jurisdictional disputes between the United States and Great Britain. ${ }^{9}$ The fact that substantive conflicts between the British rules and the (illegitimate) U.S. rule might be resolvable through one mechanism or another is beside the point. These jurisdictional disputes have centered on how broadly the "effects" theory should be construed in matters of economic policy, with the British position consistently being that it should play a very little role in economic matters, and the American position being that the theory has wide scope when significant economic effects in the United States result from activities abroad. U.S.-U.K. enforcement disputes have tended to focus on the breadth of American discovery rules, and in particular, the

6. Some of the cases illustrating that conflict are Westinghouse Elec. Corp. and Duquesne Light Co., 16 O.L.R. 273 (1977); Gulf Oil Corp. v. Gulf Canada Ltd., 1980-1 Trade Cas. (CCH) I 63,285 (Can. S. Ct. 1980); In re Uranium Antitrust Litig., 480 F. Supp. 1138 (N.D. Ill. 1979); In re Westinghouse Elec. Corp. Uranium Contracts Litig., 563 F.2d 992 (10th Cir. 1977) (deferring to Canadian interests). See also Canadian Practices in International Law during 1978 as Reflected Mainly in Public Correspondence and Statements of the Department of External tffairs, 1979 Can. Y.B. IN'T'L L. 334, 33638 (comp. by M. Copithorne) (Diplomatic Note of Canada to the United States).

7. The principal British laws are: the Competition Act 1980; the Restrictive Trade Practices Act 1976; and the Fair Trading Act 1973. These laws are reproduced in A, Competition Law in Western EUROPE AND THE USA, pt. 3, § UK/L (United Kingdom/Legislation) (D. Gijlsira ed. 1976). For a general discussion of the British laws, see V. KORAH, Competrrion Law of Britain and the Common Market (3d ed. 1982).

8. Treaty Establishing the European Economic Community, Mar. 25, 1957, 298 U.N.T.S. 47, 48 (entered into force Jan. 1, 1958).

9. See, e.g., British Nylon Spinners Ltd. v. Imperial Chem. Indus. Ltd., [1953] I ch. 19 (C.A. 1952), [1955] ch. 37 (C.A. 1954) (admittedly decided prior to the British legislation. suprn note 7 , and prior to the British accession to the EEC); In re Ocean Shipping Antitrust Litig., 1982-1 Trade Cas. (CCH) ๆ 64,585 (S.D.N.Y. 1982); Rio Tinto Zinc Corp. v. Westinghouse Elec. Corp., [1978] 1 All E.R. 434 (H.L. 1977); Laker Airways, L.td. v. Pan Am. World Airways, Inc., 604 F. Supp. 280 (D. D.C. 1984); Laker Airways, Lid. v. Sabena, Belgian World Airlines, 731 F.2d 909 (D.C. Cir. 1984). See generally D. Rosenthal \& W. Knighton, National Laws and International Commerce: The Problem of Extraterritoriality (1982). 
American penchant for collecting every document conceivably relevant to the dispute at hand. Again, the conflict over the breadth of enforcement jurisdiction is independent of the degree of similarity or difference that exists in the substantive law that will govern the case.

\section{III}

\section{Devices for Resolving JuRisdictional Conflicts}

A variety of devices for resolving conflicts of jurisdiction have been developed. The first type of device is allocational in nature. These allocational rules assign litigation to one court system or another from the outset of a case. One kind of allocational rule is hierarchical. This rule attempts to create a pre-existing hierarchy among the various bases for prescriptive jurisdiction. The country where the activities took place, with the "pure" territorial jurisdiction, may have the highest claim; the country that wishes to prescribe rules for its nationals might be next; and the country wishing to protect itself against adverse effects from abroad might be last. For any given conflict, it is necessary only to ascertain the basis of each country's claim to prescriptive jurisdiction, and to allocate jurisdiction to the country whose claim is highest on the list. Another allocational rule is the "jurisdictional rule of reason" originally proposed by Kingman Brewster. ${ }^{10}$ In antitrust cases, that rule requires the court to weigh factors like the relative significance of the conduct within each country; the extent to which there is an explicit purpose to harm or affect the forum nation's consumers or the business opportunities of its citizens; the relative seriousness of effects in the forum nation compared with those abroad; the nationality or allegiance of each of the parties, or the corporate location of businesses; the fairness of applying forum law to the litigants; the degree of conflict between the laws and policies of the two nations; and the extent to which conflict can be avoided without seriously impairing the interests of either country. Employing this kind of balancing process will reveal the "best" basis for prescriptive jurisdiction in the particular case.

It is also possible to take a consequential approach to jurisdictional conflicts, under which the basic conflict is ignored and attention is focused instead on the practical problems that arise from the competing interests of each nation. If the conflict were over prescriptive jurisdiction, as it was in the Watchmakers case, this approach would require the court to wait and see whether existence of the U.S. rule prohibiting cartels ever actually conflicted as a practical matter with the Swiss rule condoning a cartel structure in the Swiss watch industry. Actual conflict, in this sense, might be avoided either if the defendants prevailed on a nonjurisdictional ground or if intervening events mooted the case. The consequential approach relies heavily on the fact

10. K. Brewster, Antitrust and American Business Abroad 446-448 (1958). Atwood coauthored the influential revision of this book. J. Atwood \& K. BrewsTer, ANTITRUST AND AMERICAN Business Abroad (2d ed. 1981). 
that the broad theoretical sweep of the effects jurisdiction theory is seldom carried to its logical extreme in practice. If the metaphysical jurisdictional conflict between nations never translates into a practical dilemma for the regulated party, a strong argument exists for disregarding the metaphysical. The consequential approach has the effect of undervaluing the policy of the state that has chosen not to regulate, while imposing the costs of litigating on the affected parties even if the final outcome produces an acceptable resolution of the conflict. Enforcement jurisdiction clashes are typically resolved by U.S. courts in a consequential way. Discovery conflicts in which U.S. law appears to permit discovery into certain matters while a foreign blocking statute appears to prohibit it are commonplace. Following the famous Interhandel case, ${ }^{1}$ a U.S. court will issue an order requiring discovery and will determine whether the foreign litigant complies in good faith. Once this process has been exhausted, the propriety and severity of sanctions for noncompliance can be assessed most accurately.

The last approach to conflict resolution at the jurisdictional stage may be thought of as an absolutist one. Once a particular country is satisfied that its own claim to jurisdiction is validly based, both the desirability and the need to adopt any conflict avoidance mechanism vanish. The famous Alcoa antitrust decision adopted an absolutist approach when Judge Hand concluded that U.S. jurisdiction existed whenever the foreign parties intended to affect U.S. commerce and their conduct had an actual effect within the United States. ${ }^{12}$ Some applications of the jurisdictional rule of reason have been more absolutist than allocational. If U.S. jurisdiction appears to be reasonable upon consideration of the six, eight, or ten appropriate factors, the court proceeds with the case regardless of the potentially superior claim of another country. ${ }^{13}$

Ordover and Atwood: Allocational Rules in Operation

Both Ordover and Atwood adopt an allocational approach to the resolution of jurisdictional conflicts. Although Ordover eventually concedes that "if the effect in the United States is substantial in absolute terms, irrespective of the effect abroad, this ought to be enough to claim jurisdiction," 14 which sounds like an absolutist approach, his paper is devoted mostly to the establishment of allocational rules. With a rather idiosyncratic use of the term "foreign sovereign compulsion," Ordover argues that jurisdiction should be allocated partly on the basis of the kind of industrial

11. Societe Internationale pour Participations Industrielles et Commerciales v. Rogers, 357 U.S. 197 (1958).

12. United States v. Aluminum Co. of Am., 148 F.2d 416, 444 (2d Cir. 1945)

13. See Laker Airways Lid. v. Sabena, Belgian World Airlines, 731 F.2d 909 (D.C. Cir. 1984); Uranium Antitrust Litig., 617 F.2d 1248, 1254 n.23 (7th Cir. 1980).

14. Ordover, Conficts of Jurisdiction: Antitust and Indistrial Policy, Law \& Contemp. Probs., Summer 1987, at 165, 176-77. 
policies the countries in question are pursuing and partly on the basis of the single-firm or multiple-firm nature of the challenged conduct. His version of the sovereign compulsion defense does not include the usual concerns about whether the foreign government actually compelled behavior or encouraged or tolerated it, or about whether the foreign order was issued and took effect within the territory of the foreign government. Instead, Ordover's version appears to be synonymous with election of the foreign rule over the U.S. rule. ${ }^{15} \mathrm{He}$ advocates a broad "sovereign compulsion defense" - that is, primacy for the permissive country's jurisdiction to regulate-when singlefirm conduct or industrial policies designed to cure market failure or to pursue some socioeconomic objective are at issue. When the industrial policy is designed to transfer firms' profits or consumer surplus from abroad to the regulating country, or when hard-core collusive behavior is at issue, he advocates a narrow "sovereign compulsion defense," under which jurisdictional primacy is allocated to the country that is attempting to prohibit the conduct. ${ }^{16}$

Atwood's allocational rule would operate quite differently. It is essentially hierarchical in nature: The country in which a "pure export cartel" meeting his criteria was established would automatically have the higher claim to prescriptive jurisdiction. ${ }^{17}$ Since that country obviously has declared the cartel to be legal, U.S. courts should decline any invitation to examine the possible illegality of the cartel under U.S. law by refusing to accept jurisdiction over the case. As hierarchical rules go, Atwood's is quite ad hoc. If his arguments were to be generalized, a hierarchical rule for every kind of possibly anticompetitive arrangement that exists in world affairs would have to be found. One might decide, for instance, that distributional arrangements are always governed by the laws of the place of distribution, that mergers are always governed by the place where the formal transfers of assets or stock take place, and that cartels not meeting Atwood's criteria are governed by the law of each place in which sales are actually made. Conflicts scholars will recognize in this scheme a strong resemblance to the approach of the first Restatement of Conflicts, under which a fixed rule for each kind of conflict

15. This could be phrased more generally as an election of the permissive competition rule over the restrictive competition rule. In the past, the United States has always had the restrictive rule and the foreign government has always had the permissive rule. Developments in U.S. antitrust doctrine of recent years, however, in areas such as vertical restraints, leave open the clear possibility of a future conflict in which the U.S. rule is the permissive one and the foreign rule is the restrictive one. See, e.g., U.S. Dep't of Justice, Vertical Restraints Guidelines, reprinted in 50 Fed. Reg. 6263 (1985); Continental T.V., Inc. v. GTE Sylvania, Inc., 433 U.S. 36 (1977). Compare the EEC rules on selective distribution, discussed in Schroeter, The Application of Article 85 of the EEC Treaty to Distribution Agreements_Principles and Recent Developments, 1984 Fordham Corp. L. Inst. 375. See also AEGTelefunken v. EEC, 1983 E. Comm. CT. J. REp. 3151 . For simplicity, the discussion in the text follows the traditional scenario, in which the United States is trying to prohibit something that a foreign government wishes to permit.

16. Ordover, supra note 14 , at 176.

17. Atwood, Conflicts of Jurisdiction In the Antitrust Field: The Example of Export Cartels, LAw \& Contemp. Probs., Summer 1987, at 153, 160-164. 
was offered. ${ }^{18}$ They will also note that this approach has been rejected by modern writers as being unduly rigid, insensitive to the policy reasons for choosing one law or another, and in many situations unworkable in practice. ${ }^{19}$ Atwood himself, of course, does not suggest generalizing his solution, and he implicitly concedes that the "pure export cartels" that he addresses are quite rare. He may prefer a hybrid solution, under which hierarchical allocational rules govern some jurisdictional conflicts, absolutist rules govern others, and consequential solutions remain for the rest. Such a system would hardly be conducive to conflict reduction, however, since the rules for conflict resolution would themselves become a fertile source of disagreement.

\section{V \\ Comment and Criticism}

The merits and demerits of the two principal proposals lie at opposite ends of the spectrum. Ordover's emphasis on the underlying motivation of industrial policy is particularly interesting, because he persuasively argues that the welfare effects and externalities of different kinds of policies will vary, and the legitimate foreign interest in overriding another country's policy is in part a function of what the regulating country is trying to do. His system also has the virtue of avoiding the perennial debate about "true" compulsion versus other modes of expression of government policy. The problem with Ordover's approach is more practical. It seems utterly unworkable in practice, and if it were attempted, the approach would lead to far greater tensions between the competing nations than does the present system. This is because no "sovereign compulsion defense" as he defines it could be recognized, or even defined in scope, until the U.S. court had undertaken an elaborate investigation of the real foreign policy that lay behind the private parties' conduct.

It would not be easy, in practice, to distinguish between industrial policies motivated by socioeconomic concerns and those policies designed to capture profits and surplus from foreigners. The $O P E C$ case provides a useful test. ${ }^{20}$ Was the cartel motivated by socioeconomic concerns? Certainly. All of the member countries of OPEC attempted to use their oil wealth to improve the lot of their citizenry. Was the cartel designed to capture foreign consumer surplus? Yes. OPEC was a concerted and successful effort to shift the terms of trade in favor of the resource-rich countries. Was OPEC designed to correct for some kind of market failure? Conceivably so. Oil and gas fields are not necessarily exploited at the optimal rate in the absence of some kind

18. Restatement of the Law of Conflict of Laws (1934). See generally J. Beale, A Treatise ON THE Conflict of LaWs (1935).

19. See, e.g., A. Ehrenzweig, A Treatise on the Conflict of Laws \$§ 1-5 (1962); R. Leflar, American Conflicts Law (3d cd. 1977); R. Weintraub, Commentary on the Conflict of Laws (3d ed. 1986).

20. International Ass'n of Machinists v. OPEC, 477 F. Supp. 553 (C.D. Cal. 1979), aff'd. 649 F.2d 1354 (9th Cir. 1981), cert. denied, 454 U.S. 1163 (1982). 
of regulation. What should a court do under those circumstances? Put differently, would the task of the California federal district court have been any easier when the Machinists filed their lawsuit if industrial policy analysis had been necessary? It seems unlikely. Moreover, Ordover's distinction between single-firm and concerted behavior would not have resolved the conflict, since he condemns collusive behavior like OPEC's more harshly. In the end, neither classification based on industrial policy type nor a distinction between single-firm and collusive activity seems likely to function well as a conflict reduction or resolution device. ${ }^{21}$

Atwood's approach is eminently practical. Anyone should be able to look at a particular export cartel and determine whether its members include only producers from within a single country's territory (formally, of courseshareholder identity would have to be disregarded); whether the cartel has been publicly registered; and whether its overt collaborative behavior is confined strictly to the territory of the country in question. One difficulty here is the absence of a significant relationship between these characteristics and the legitimate regulatory interest of either country. The cartels that Atwood has defined seem to correspond almost perfectly with Ordover's third category-those with no economic justification other than a transfer of wealth from foreigners to the sponsoring country. The mere fact that many countries actually sponsor this kind of cartel in no way suggests that a gentlemanly "hands off" attitude is the best resolution of the conflict. The enactment in the United States of the Foreign Trade Antitrust Improvements Act of $1982^{22}$ points to a different rationale for tolerance of export cartels, and to a different type of conflict resolution. That Act established that the U.S. antitrust laws regulate only the U.S. market. The laws do not exist for the protection of foreign consumers, except insofar as foreigners are the incidental beneficiaries of the protection of U.S. consumers. The United States allows export cartels to form as long as no impermissible U.S. effect is created, and it leaves foreign countries free to regulate those cartels, depending on their substantive economic policies and the existence of significant economic effects within their territories. The allocational rule is based on the presence or absence of effects within a territory. This rule is preferable to one that, almost perversely, allows the country attempting to seize foreign producer or consumer surplus to regulate, and forbids regulation to the country where the misallocation of resources is felt most strongly.

Part of Atwood's argument rests on the proposition that the United States has now "accepted" a full-blown jurisdictional rule of reason, which in his view appears to operate in an allocational way rather than absolutely. The

21. See, e.g., Matsushita Elec. Indus. Co. v. Zenith Radio Corp., 475 U.S. 574, (1986). Compare, for example, the treatment of IBM in the case before the Commission of the European Communities (the settlement of which was reported in 17 Bull. Eur. Communities (No. 10) 96-103 (1984) and in 17 Bull. Eur. Communities (No. 7/8) 7-9 (1984)), with the dismissal of the U.S. government's case against the same company, discussed in In re IBM, 687 F.2d 591 (2d Cir. 1982).

22. Pub. L. No. 97-290, $\S 402,96$ Stat. 1246 (codified at 15 U.S.C. $\S 6 a(1982)$ ). 
state of the law, however, is less clear than he suggests. Some courts have adopted an exceptionally open-ended jurisdictional rule of reason, and others have fundamentally rejected jurisdictional rules of reason as beyond the competence of a court. ${ }^{23}$ Representatives of the Department of Justice have testified before Congress that the kinds of factors courts should weigh should be objectively ascertainable, basically taking an absolutist approach to the problem. ${ }^{24}$ Unless and until Congress speaks to the subject or a definitive resolution appears from the Supreme Court, the most that can accurately be said about jurisdictional rules of reason is that they have been, for the last decade, the subject of experiments in the lower courts of the United States. ${ }^{25}$

\section{VI}

\section{Conclusion}

Conflicts of jurisdiction to regulate economic conditions are not likely to disappear from the modern world. For the same reason that protectionism in trade laws sends a siren song to national legislatures, and beggar thy neighbor policies have a way of looking better than they actually are, efforts to reap monopoly rents from foreigners without paying a domestic price in the form of resource misallocations are likely to continue. Furthermore, as Ordover has noted, competition is only one of a number of possible industrial policies a country might adopt, and other policies may be more compelling to particular nations at particular times. The resolution of these conflicts will never be easy. The most effective and simplistic resolutions, such as the abolition of all forms of prescriptive jurisdiction other than pure territorial jurisdiction, are fatally flawed in light of the transnational character of the bulk of today's economic activity. No one would seriously favor allowing multinationals to play off one country against another or to relocate in permissive regulatory havens with impunity.

With the acceptance of effects jurisdiction, however, more sophisticated conflict resolution devices become necessary. The following solution may help to address some of the problems noted in the Ordover and Atwood articles. As a first cut, absolutist rules of jurisdiction that require significant effects in the regulating country should be formulated. This kind of rule necessitates the least amount of interference by one country's courts with another country's policies. At the same time, absolutist rules maintain a

23. Laker Airways Ltd. v. Sabena, Belgian World Airlines, 731 F.2d 909, 952-53 (D.C. Cir. 1984) (rejecting jurisdictional balancing test); National Bank of Canada v. Interbank Card Ass'n, 666 F.2d 6, 8-9 (2d Cir. 1981) (less reliance on "rule of reason"); Mannington Mills, Inc. v. Congoleum Corp., 595 F.2d 1287 (3d Cir. 1979) (advocating broad jurisdictional balancing test); Timberlane Lumber Co. v. Bank of Am., 549 F.2d 597, 606-15 (9th Cir. 1976), on remand, 574 F. Supp. 1453 (N.D. Cal. 1983), aff'd, 749 F.2d 1378, 1382-86 (9th Cir. 1984), cert. denied, 472 U.S. 1032 (1985) (broad jurisdictional balancing test).

24. See e.g., The Foreign Trade Antitrust Improvements Act of 1985: Hearings on S. 397 Before the Senate Comm. on the Judiciary, 99th Cong., Ist Sess. (1985) (statement of Charles F. Rule). See also S. 2164 , 99th Cong., 2d Sess., 132 Cong. Rec. 2288-89 (1986) (introduced Mar. 7, 1986, by Sen. Strom Thurmond).

25. See Revised Restatement, supra note 1. 
reasonable link between jurisdictional rules and substantive policies. To the extent that conflicts remain, as some surely will, consequential devices can be used as a secondary corrective measure. Those devices include the foreign sovereign compulsion or act of state defense, which remain after the initial jurisdictional determination has been made. Many times the substantive law creating liability will not extend to behavior commanded by a competent sovereign, just as the antitrust laws do not ban certain practices undertaken under the aegis of state regulation. ${ }^{26}$ Courts will refuse to look into the validity of certain acts of foreign states, which may include some kinds of foreign compulsion. ${ }^{27}$ Finally, in the enforcement context, sovereign compulsion may be taken into account by a court in deciding how severely to penalize less than complete cooperation. If the consequential devices also fail to resolve the jurisdictional conflict, it may be necessary to resolve the problem diplomatically, rather than legally.

At the international level, the best that can be hoped for is conflict management, rather than conflict abolition. The analytical scheme proposed here, if applied properly, would accomplish that goal not only for antitrust but for any area in which the interests and policies of many nations are so inevitably tied together.

26. See Southern Motor Carriers Rate Conference, Inc. v. United States, 471 U.S. 48 (1985); Parker v. Brown, 317 U.S. 341 (1943).

27. See Banco Nacional de Cuba v. Sabbatino, 376 U.S. 398 (1964). See also International Ass'n of Machinists v. OPEC, 477 F. Supp. 553 (C.D. Cal. 1979); Underhill v. Hernandez, 168 U.S. 250 (1897). 